\title{
The Leadership Style of Hasballah Bin Muhammad Thaib of East Aceh Regency Period 2012-2017
}

\author{
Muhammad Bin Abubakar ${ }^{1}$, Zulhilmi² $^{2}$, Teuku Muzaffarsyah² \\ ${ }^{I}$ Public Administration Masters Program, Faculty of Social and Political Science, Universitas Malikussaleh \\ ${ }^{2}$ Department of Political Science, Faculty of Social and Political Science, Universitas Malikussaleh \\ *Corresponding author. Email: muhd.a.bakar@gmail.com
}

\begin{abstract}
This paper tried to analyze the leadership style of local regent in the making decision on the welfare of the people in the East Regency (Kabupaten Aceh Timur) of the Aceh Province. The case of Hasballah bin Muhammad Thaib. The study focused on his policies that contributed to his administration success in bringing development to the East Aceh Regency. In so doing, the paper had adopted the leadership theory that assumed that leader's style could be the generator for the better running of governance; and therefore open opportunity for the incumbent to win the election. Accordingly, this paper would answer the following questions, what does Thaib's style of leadership; and how the style had improved the effectiveness and efficiency of the local government in providing services for the public in the regency. To answer those questions, it had conducted deep interview and focus group discussion, so that it could explain the phenomena within its natural setting, to suit the aim of the qualitative approached. The collected data would be displayed and verified, so that they were valid and reliable. It was found that, leadership style had positive impact on the effectiveness and efficiency of the local governance in providing service to the public. Thus, it was concluded that Thaib's self-discipline and self-motivated had contributed to the rapid development of the East Aceh regency. Finally, it was expected that the finding of this study would serve better the need for better leadership at the local government and provincial government of Aceh Governance
\end{abstract}

Keywords : Leadership Style, high self-discipline and motivation, local election and Kabupaten Aceh Timur

\section{INTRODUCTION}

Strong and the style of Leadership are among determinant factors for the smooth running of a government that simultaneously would contribute to the rapid development of the local government in the regency. Hasballah Bin Muhammad Thaib, being one of prominant ex-combatant of the Free Aceh Movement [Gerakan Aceh Merdeka / GAM ] who won the local head election in 2012 is an interesting case to be studied. Despite of his low level education and spent much of his time as guerillas in the juggle of East Aceh, was nothing to be compared to other candidates who were well educated and well experienced in running the government. His affiliation to the GAM's elite had won him the place as the number one man in the regent. However, as soon as he took the office, Hasballah or known as Rocky took the most controversial step that had surprised all people in the region, particularly civil servants under his administration. His emphatic style of leadership had rendered him respect from his colleges and opponents. Within 100 days of his leadership, many appreciated his disciplinary policy toward the public servants, for the governance of East Aceh had improved her service to the public. In addition to that many more changes and improvement took place in the regency. $\mathrm{He}$ had brought life to the dead city of Idi. Accordingly, this paper which was based on field research would explore the success of Rocky administration in 
improving the public service and bringing development to the East Aceh region. Thus, this paper would address the following questions: how is the leadership of Rocky in managing his administration? And what do the dominant policies that contribute to the success of his administration.

\section{LITERATURE REVIEW}

In order to suit the standard of scientific paper, this paper had conducted review of literature on the concept of leadership. So that a better picture on Rocky's style of leadership could be presented proportionately. The literatures have been classified based on the subject matter covered.

\subsection{Leadership}

The concept of leadership is rooted from the word, leader which means someone who lead or someone who is entrusted with authority to lead. When the term leader is affixed with ship, means management or administration. According to Moorhead dan Griffin (2013:46) where leadership is an individual who is able to influence the behavior of others without having to rely on violence and be accepted by others as a leader. Sedarmayanti (2009:199) argue that leader are capable of influencing others to do or not do something as desired. Those who incarnate leadership while the leader is someone who runs the management. The same person should run two things effectively. They do or run the leadership. The word "leader" reflects the position of a person or group of people in a particular hierarchy within the organization, who has subordinates, because the position in question obtains or has formal power, and responsibility. Leadership is part of manjemen functions that occupy strategic positions in the system and hierarchy of work and responsibility in an organization (Baidan dan Aziz, 2014:126)

The leader is someone who has a certain role, hence leading the Syaiful of all (2009:114), saying that leadership comes from the word leader, which is a known person and seeks to influence his followers to realisir his vision. Other. between leadership as a position and leadership as a social process or as a position. Kartini Kartono (2010:87-89) explained that the type of leadership is divided:

\subsubsection{Charismatic Type}

A type that has great appeal and carrying, so it has a large following. The loyalty and obedience of his followers arises from trust in the leader. Leaders have the skills gained from the omniscient.

\subsubsection{Paternalistic type}

Paternalistic leadership types are more about traits such as considering their subordinates immature, overly protective. Furthermore, it is rare for subordinates to make decisions and always be omniscient and omniscient.

\subsubsection{Authoritarian Type}

Authoritarian leaders have aspects such as the leader of the organization as his and the leader acts as a dictator and how to move subordinates by force and threat.

\subsubsection{Military Type}

In this type leaders have the qualities of demanding harsh and rigid discipline and then use more government systems. Wanting absolute decisions from subordinates as well as excessive formalities, unwilling to accept advice and criticism from subordinates, the nature of unilateral communication

\subsubsection{Democratic Type}

This type of democracy prioritizes the issue of cooperation so that there is coordination of the work of all subordinates. Democratic leadership faces potential individual attitudes, willing to listen to constructive suggestions and criticisms. So the leader weighs in on the activities, which begin to determine the purpose of decision making, discipline. 


\subsubsection{Liazez Faire}

In liaizaz faire's leadership, the leader practically does not lead, letting his group and everyone do all by themselves. The leader does not participate in any of his group's activities. All work and responsibility must be done by the subordinates themselves. is a symbol leader, and usually lacks technical skills. He had no authority and could not control his subordinates, was unable to co-ordinate work and was powerless to create a good work atmosphere.

According to Danang Sunyoto (2015 : 30) states that leadership is as a process of influencing the activities of an individual or group to achieve a goal in a particular situation. Thus leadership is an important part of the management, so in this case managers must plan and organize and influence others to achieve their goals.

\subsection{Leadership style}

Leadership style is a dimension of the behavior of a leader who is able to control the situation of the institution he leads. Thoha (2013: 49) describes that leadership style is the norm of behavior used by a person at a time when the person is influencing the behavior of others as he or she sees. Sementara Rivai (2014:42) states that leadership style is a set of traits that leaders use to influence subordinates in order for organizational goals to be achieved or it can be said that leadership styles are patterns of behavior and strategies favored or often applied by a leader. Leadership style that demonstrates, directly or indirectly, about a leader's belief in subordinate abilities. Fielder (Robbin: 2015: 28) Leadership style has a key factor in leadership success which is the basic leadership style in individuals. Filder it also assumes that if a situation requires a leader to be task-oriented and the person in that leadership position is relationship-oriented and one of the situations that must be modified or the leader must be replaced to achieve optimal effectiveness.

\section{METHODOLOGY}

\subsection{Research Approach}

The type of research used in this study is qualitatively producing descriptive data analysis in the form of written or oral words from people and observed behavior, Moleong J lexy ( 2012: 4) This type of qualitative research uses scriptive-qualitative analysis methods, as well as exploratory qualitative. The approach is used to analyze the Regent's Leadership Style Aceh Timur H. Hasballah Bin Muhammad Thaib, 2012 - 2017 Period, and reviewed from inhibitory and supporting factors such as available resources, communication between stakeholders, implementor attitudes towards programs and environmental conditions related to social, economic and political conditions. based on the facts by presenting social phenomena in the field completely according to the aspects examined.

\subsection{Research Location}

The focus of study is on the style of leadership of Bupati H. Hasballah Bin Muhammad Thaib located in Kabupaten Aceh Timur

\subsection{Data collection and analysis}

\subsubsection{Observation}

The collection of this research data will be conducted through observation activities or direct observation of analytical objects to explore relevant and important aspects as the basis of analysis and interpretation to be carried out. Observations in this field aim to explore the possibility of missing information 


\subsubsection{Interview}

This research in order to obtain valid or accurate data in addition to observation, data collection will be conducted through indepth interview is intended to obtain qualitative data as well as some information or information from informants. This in-depth interview was conducted with a key informant who is considered to have knowledge of the.

\subsubsection{Documentation}

Documentation refers to the Undang-Undang No. 32 Tahun 2001 pemerintah Daerah and Undangundang No 11 Tahun 2006 Tentang pemerintah Aceh procedures and other supporting documents. The documents include letters, data data/information, records, photographs of activities, tape recorder recordings and other relevant documents as well as files of reports that have been compiled by various parties about the objects examined.

\subsection{Data Analysis}

This research data is obtained primaryly meaning it is obtained directly in the field and still abstract so that it must be reduced and perform coding and interpretation of the data so that the initial results must be verified so that the final results are obtained in a scientifically specific data process.

\section{RESULTS AND DISCUSSION}

\subsection{H. Hasballah Bin Muhammad Thaib or Rocky's Policies}

The policy taken by a regional head should reflect the contribution of the aspirations of the community because this is a real denocracy process. The most important influence on policy lies in the leadership style of a regional head of character dimensions. This is the main basis of a political process that takes place in East
Aceh. East Aceh regency which was originally a backward area is now becoming developed with the increasingly active economic center in Idi Rayeuk which is the capital of the District. The first policy was carried out by H. Hasballah Bin Muhammad Thaib namely by revamping and structuring in the ranks of the East Aceh government. One of them is to apply performance disiplim to bureaucrats in the government environment of East Aceh Regency.

The eradication of bureaucratic systems and the application of discipline is necessary to maximize service to the community. Public services must be primed, practical, economical and dynamic then to realize Good Governance. Setelah hal ini dilakukan maka H. Hasballah Bin Muhammad Thaib bersama wakilnya Syahrul Bin Syamaun or often greeted "Linud" is a solid partner in building the face of East Aceh for the better. Once the bureaucracy is properly constructed, public services can run to the maximum

.Rocky also see the potential of qualified natural resources in east Aceh. Several clusters of oil potential development in East Aceh were able to bring significant industrialization impacts Poin A Block Exxon mobil which has a backup exploited by the PT Medco E\&P Malaka. Oil drilling areas are located in sub-districts Pante Bidari that continues to grow. Furthermore, natural resources in the region Ranto Peureulak also began to develop this into the most important thing in the potential of industry in East Aceh Regency. This process is also being supervised by the Regent of East Aceh in addition to also looking at the environmental impacts that should be considered

He also concrete measures with more focus on existing government infrastructure facilities in the region Idi Rayeuk. Facilities for building government buildings as part of smoothing the wheels of government organization of East Aceh Regency. In addition to physical infrastructure, the increase in human resource potential is also improved so that it is 
able to compete with other regions in Aceh. This can be seen a very drastic change to the face of the District Capital which is increasingly active. In addition, public facilities are also a good process built for the benefit of the people in East Aceh Regency.

\subsection{Leadership Characteristics of $H$. \\ Hasballah Bin Muhammad Thaib}

The character of H. Hasballah Bin Muhammad Thaib leadership is more to real action and the effectiveness of the most important performance. In applying discipline he awards and sanctions for the government apparatus of East Aceh Regency. This has a huge influence on the maintenance of the ideal government. Infrastructure and improvement of the character of the community, during his tenure as regent of East Aceh Regency. During his tenure Rocky all development lines developed potential. In addition to that, he also many do a lot of work in taking policies that are able to benefit the public in general.

His style benefits by the community. The development carried out by the East Aceh Government is very prudent in continuing the construction of government facilities in Idi Rayeuk. So far, East Aceh has not been so advanced after being developed into three regions. this is what makes him to perform its role as regent to the maximum and improve practical, economical and dynamic public services. The implementation of the policy of the regent of East Aceh is also a positive contribution not only in Aceh but for the national in general.

The pattern of leadership of the Regent of East Aceh is very populist and is also known as the realm of combatant organizations. It is also a characteristic of the capable who become a role model in the body of the organization KPA and Aceh Party. Furthermore, Rocky in implementing the policy is really well implemented. Makes him increasingly attached to people.
Rocky style of leadership, able to create a range of KPA and Aceh Party united and solid.

1. Able to develop East Aceh Regency by building government infrastructure collectively.

2. H. Hasballah Bin Muhammad Thaib as the Regent of East Aceh is close to the clerical elements or dayah leaders and is able to bring the community closer to him.

3. The pattern of leadership is supervised and assertive so that it has a great influence on East Aceh Regency.

Rocky melakukan tiga trobosan yang tergambar bagan di atas. Jadi target dalam perform three boredoms drawn by the chart above. So the target in developing the potential of East Aceh area by doing the trobosan in showing that east Aceh Regency is good and dignified It is necessary to give the development that is done by develop the potential of East Aceh region by doing the trobosan in showing that the District of East Aceh is good and dignified

\subsection{Development of people's Economic Sector in East Aceh}

Being elected as the Bupati and Deputy of Bupati Aceh Timur, they hope for mayarakat in building the area towards East Aceh going forward. Economic potential for small communities in developing agropolitan and minapolitan potential minapolitan dimension is an excellent potential for the fishing community. Fishery development that is a major mainstay for coastal areas in the eastern region of Aceh. The fishermen in East Aceh continue to improve and develop their productivity in producing quality fish that are able to supply the needs of fisheries to the North Sumatera. In addition, the fishery sector is also able to prosper the lives of the general fishing community in East Aceh Regency. So the Regent's Policy in supporting this minapolitan was developed one of them in the sub-district Idi Rayeuk they become hope for 
mayarakat in building the area towards East Aceh forward. Economic potential for small communities in developing agropolitan and minapolitan potential. minapolitan dimension is an excellent potential for the fishing community. The development of fisheries that became a major mainstay for coastal areas in the eastern region of Aceh.beberapa ng melakukan penjualan ikan hingga pengiriman keluar Aceh Timur atau luar Provinsi Aceh. Various programs and strategies and policies are neatly structured in building a more developed fishery sector. Construction of fish auction center in Kuala Idi Rayeuk which is the center of minapolitan that can grow rapidly. Rocky also see the fishery sector as a potential for East Aceh. This continues to be focused by the Government of East Aceh Regency and develops economic potential for the People of Nelayan. In addition to the Minapolitan Government of East Aceh Regency also focused on agropolitan sector.

Agropolitan is an aspect of economic sector development for farmers in East Aceh Regency. This is based on the large number of agricultural areas, both rice fields and plantations that have great potential for the welfare of the peasant community.

Agrotechnology dimension becomes the most important dimension in developing agricultural sector in East Aceh development is dotted in the infrastructure sector as supporting infrastructure. for the community in growing the economy, this program was built by Rocky to remote villages untouched by development. The goal is to facilitate the supply of agriculture to be traded to the city. During his leadership many changes and development in East Aceh area. Sehingga pada 2017 Local Head Election, this pair and win the Regent's Election competition for the second time.

\section{CONCLUSIONS}

Finally it can be understood the leadership style of the Regent of East Aceh H. Hasballah Bin Muhammad Thaib. That in carrying out its policy more to the strategy of economic growth of the community and the acceleration of government infrastructure development in terms of the course of the government governance process in service to the community. The people of East Aceh feel the performance of the District government under the leadership of H. Hasballah Bin Muhammad Thaib and Syahrul Bin Syamaun. Solid leadership of the couple H. Hasballah Bin Muhammad Thaib and Syahrul Bin Syamaun east Aceh as a slogan "Aceh Timu Bereh". This can be considered the development of East Aceh Regency is very good and getting better.

The development of minapolitan and agropolitan sectors is a major mainstay in the development of the real sector of the economy for small communities. Leadership style H. Hasballah Bin Muhammad Thaib also able to influence the development of the two sectors so as to have a good impact on East Aceh Regency. Assertiveness and prudentness are the most important things in the administration of East Aceh Regency.H. Hasballah Bin Muhammad Thaib able to approach all elements of society in his leadership. In addition, the strategy of accelerating the development of government infrastructure has also reached the $100 \%$ stage so that government governance can run its maximum

Development strategies carried out by $\mathrm{H}$. Hasballah Bin Muhammad Thaib and Syahrul Bin Syamaun as a couple of Regents and deputy Regents remain solid so that aspects of development are really felt by the people of East Aceh Regency. Because of their success in their leadership style, 2017 local election the community instead wants the couple to return to lead East Aceh for Period of 2017-2022 so that this second dipriode opportunity further strengthens the policies that have been implemented in the previous period. Hopefully the concept of development of the leadership style of the Regent of East Aceh can be adopted by other regions and especially the entire Aceh region. 


\section{REFERENCES}

Baidan, Nasharuddin \& Erwati, Aziz. Etika Islam dalam Berbisnis. Yogyakarta, Pustaka Pelajar, 2014.

Kartini Kartono. Pemimpin dan Kepemimpinan. Bandung: Rajawali Press. 2010

Moleong, Lexy J. Metode Penelitian Kualitatif: Edisi Revisi. Bandung : PT Remaja Rosdakaya. 2012

Moorhead dan Griffin. Perilaku Organisasi. Jakarta: Salemba Empat. 2013

Rivai, Vietzal. Kepemimpinan dan Perilaku Organisasi. Jakarta: PT Grafindo Persada. 2014.

Robbins, Stephen. Perilaku Organisasi. Jakarat : Penerbit Salemba Empat. 2015

Sagala, Syaiful. Konsep dan Makna pembelajaran. Bandung : Alfabeta. 2009

Sedarmayanti. Manajemen Sumber Daya Manusia. Bandung: Refika Aditama. 2013

Sunyoto, Danang. Manajemen dan Pengembangan Sumber Daya Manusia. Yogyakarta: Center for Academic Publishing Service. 2015

Sutikno, M. Sobry. Pimpinan dan Gaya Kepemimpinan (Edisi Pertama). Lombok: Holistica. 2017

Thohah,Miftah. Kepemimpinan dalam manajemen. edisi 1. Jakarta: PT raja Grafindo Persada. 2013 